\title{
Determination of cadmium and zinc levels and oxidative status in cadmium treated developing chick embryonic liver
}

\author{
Malekar Meena Bai ${ }^{1}$, SK. Haseena Bhanu ${ }^{2}$, Prof. K. Thyagaraju ${ }^{3}$ \\ ${ }^{1-3}$ (Department of Biochemistry, Sri Venkateswara University, Tirupati, India)
}

\begin{abstract}
In the present study Chick embryos of Bobcock strain were treated with different concentrations (0.04, 0.05and $0.06 \mathrm{mg} / \mathrm{egg}$ ) of $\mathrm{CdCl}_{2}$ on the day 10 (d10), day 11 (d11), day 12(d12) of embryonic development. In this study metals like $\mathrm{Cd}, \mathrm{Zn}$ were determined with ICP-OES in liver tissue of control and treated groups at different time intervals. The levels of (GSH) and activity levels of antioxidant enzymes such as glutathione peroxidase (GPx), glutathione reductase (GR), glutathione-S-transferase (GST), superoxide dismutase (SOD) and catalase (CAT) were measured in liver tissue after different time intervals ( $24 \mathrm{~h}, 48 \mathrm{~h}$ and $72 \mathrm{~h}$ ) of $\mathrm{CdCl}_{2}$ exposure. Significant induction was observed in GST activity in liver tissue after $24 \mathrm{~h}, 48 \mathrm{~h}$ and $72 \mathrm{~h}$. However, the GPx, GR, SOD, CAT and GSH levels were decreased in dose and time dependent manner. In this study $\mathrm{Cd}$ retention in the liver increased with dose level of $\mathrm{Cd}$ and this inturn caused induction in the levels of Zinc in liver tissue.
\end{abstract}

Keywords:Antioxidant enzymes, Chick embryonic liver, Cadmium, ICP-OES, Zinc

\section{INTRODUCTION}

Cadmium $(\mathrm{Cd})$ is an industrial and environmental pollutant, arising primarily from battery, electroplating, pigment, plastic, and fertilizer industries, and cigarette smoke [1]. Cd shows different mechanisms of toxicity under different experimental conditions and in various species [2-6]. Once absorbed, $\mathrm{Cd}$ is rapidly cleared from the blood and concentrates in various tissues.

The effects of $\mathrm{Cd}$ on antioxidative capacity are dual: on one hand, $\mathrm{Cd}$ can induce oxidative stress via the inhibition of antioxidants, and on the other it activates several antioxidative components as a result of a disturbed redox balance to consecutively induce signal transduction cascade. The mechanism of cadmiummediated acute hepatotoxicity has been the subject of numerous investigations and sufficient evidence has emerged to reveal reasonable mechanisms for the toxic process, although some unexplained aspects still persist. Acute hepatotoxicity involves two pathways: one for the initial injury produced by direct effects of cadmium and the other for the subsequent injury produced by inflammation. Primary injury appears to be caused by the binding of $\mathrm{Cd}^{2+}$ to sulfhydryl groups on critical molecules in mitochondria. Thiol group inactivation causes stress, mitochondrial permeability transition and mitochondrial dysfunction. Secondary injury from acute cadmium exposure is assumed to originate from the activation of Kupffer cells and a cascade of events involving several types of liver cells and a large number of inflammatory and cytotoxic mediators [7].

As Cd shows a high affinity for thiols, the major thiol antioxidant, glutathione (GSH) that is highly abundant in cells, is a primary target for free Cd-ions. Therefore Cd-induced depletion of the reduced GSH pool [8] results in a disturbance of the redox balance leading to an oxidative environment. Under natural conditions ROS are produced in organelles with a highly oxidizing metabolic rate or those possessing electron transport chains, such as peroxisomes and mitochondria. Because $\mathrm{Cd}$ is a non redox-active, non-essential element, it cannot induce ROS production directly.

The cellular redox status and antioxidant defense mechanisms are more sensitive and lower in the embryo compared to adults [9-13]. Antioxidant defense mechanisms against free radical-induced oxidative damage include the following (i) catalytic removal of free radicals and reactive species by factors such as CAT, SOD, peroxidase and thiol-specific antioxidants; (ii) binding of proteins (e.g., transferrin, metallothionein, haptoglobins, ceruloplasmin) to pro-oxidant metal ions, such as iron and copper; (iii) protection against macromolecular damage by proteins such as stress or heat shock proteins; and (iv) reduction of free radicals by electron donors, such as GSH, vitamin E, vitamin C, bilirubin and uric acid [14-20]. CAT, in animals, is a hemecontaining enzyme that converts $\mathrm{H}_{2} \mathrm{O}_{2}$ to water and $\mathrm{O}_{2}$ and these enzymes are largely localized in subcellular organelles such as peroxisomes [21].

Upon absorption in the blood, cadmium binds to albumin and is transported to the liver. Cadmiuminduced liver damage increases hepatic enzymes [22]. Metallothionein (MT), a low molecular weight metalbinding protein, binds cadmium where it is either stored in this conjugated form in the liver or transported to the kidney. Once filtered through the renal glomerulus, the cadmium-MT complex is reabsorbed in the proximal 
tubules and degraded to release free cadmium. It is this reactive cadmium ion that contributes to renal tubular toxicity while accumulating in the cortex of the kidney [23].

Cadmium can compete with heavy metals such as Zinc for their binding sites on various proteins and thus modulate their function. Zinc-binding sites such as zinc finger motifs of transcription factors and signal transducers like PKC, or of metallo-enzymes of SOD, are all targets for cadmium occupation leading to nonphysiological regulation of the protein activities. Cadmium is believed to replace zinc in its binding site on $\mathrm{Zn} / \mathrm{Cu}$ SOD, inhibiting the enzyme leading to an increased production of ROS [24]. In a model that describes the cadmium induced activation of the PKC-mediated signal transduction, $\mathrm{Cd}^{2+}$ substitutes for $\mathrm{Zn}^{2+}$ in the regulatory domain of the enzyme thus exposing the putative protein-protein interaction site [25].

In the present study, the influence of Cd on GSH, on the antioxidant defense system (AOS), its retention in liver and its effect on Zinc levels in the liver of $13^{\text {th }}$ day chick embryo was analysed. After 24, 48 and 72 hours of Cadmium exposure, the activities of enzymatic (SOD, CAT, GSH, GPx, GR and GST) components of the system were determined.

\subsection{Chemicals}

\section{MATERIALS AND METHODS}

Cadmium chloride (analytical standard), supplied by SD fine chemicals Ltd (India), was used for the study. Saline was used for preparing suspensions of Cd (volume of injection was $100 \mu \mathrm{l} \mathrm{per} \mathrm{egg).} \mathrm{Bovine} \mathrm{serum}$ albumin (BSA), 5,5'-dithiobis-2-nitrobenzoic acid (DTNB), 1-chloro-2, 4 dinitrobenzene (CDNB) were obtained from Sigma Chemical Company, USA. Standard solutions of Cadmium and Zinc metals were prepared by dilution of $1000 \mathrm{ppm}$ certified solution. Argon gas has been $99.99 \%$ purity. All other chemicals used were of analytical grade obtained from local firms.

\subsection{Egg procurement, in ovo injections and incubation}

Fertile Bobcock strain eggs procured from the Sri Venkateswara Veterinary University, Tirupati and Sri Balaji hatcheries, Chittoor, Andhra Pradesh, India were administered with 40, 50 and $60 \mu \mathrm{g}$ of Cd/egg,

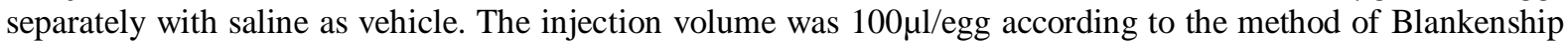
2003 [26]. The eggs were incubated with their broad ends up in an incubator. The eggs were rotated for every 1 $\mathrm{hr}$ and were examined through the Candler every day for the proper growth and viability. During all experiments, the live embryos were maintained at $37.5 \pm 0.5^{\circ} \mathrm{C}$ and a humidity of $70-75 \%$, except for brief intervals (60-120 seconds) required during the different treatment conditions. During this interval embryos experienced ambient room temperature $\left(29-30^{\circ} \mathrm{C}\right)$.

\subsection{Egg treatment and tissue processing}

The egg shell was opened at the blunt end at the top to obtain access to the air cell, where the respective test substance $(100 \mu \mathrm{l})$ was injected directly on to the inner shell membrane. Covering the hole by wax could ensure the embryos vitality for the remaining time until dissection and tissue collection. Chick embryonic liver was collected on $\mathrm{d} 13 \mathrm{after} 24 \mathrm{hr}(\mathrm{d} 12), 48 \mathrm{hr}(\mathrm{d} 11) \& 72 \mathrm{hr}$ (d10) initial administration of the test substance. The liver of $13^{\text {th }}$ day was dissected out, weighed and washed using chilled saline solution. Tissue was minced and homogenized $(10 \% \mathrm{w} / \mathrm{v})$ in appropriate buffer $(\mathrm{pH} 7.4)$ and centrifuged $(3000 \mathrm{~g}$ for $10 \mathrm{~min})$. The resulting clear supernatant was used for following antioxidant assays.

\subsection{Estimation of Protein, GSH and antioxidant enzymes}

The protein was determined according to the method of Lowry 1951 [27] using BSA as standard [28]. The estimation of total GSH was carried out by the method of Griffith, 1980 [29]. SOD activity was determined according to the method of Misra and Fridovich, 1972 [30] at room temperature. CAT activity was measured in the PMF by the method of Aebi, 1974 [31]. GR activity was determined by a slightly modified method of Carlberg and Mannervik, 1985 [32]. at room temperature. GST activity was assayed by the conventional method of Habig et al., 1974 [33]. GPx assay was carried out by monitoring the oxidation of NADPH in a recycling assay as described by Wendel, 1981[34].

\subsection{Cadmium and Zinc estimation}

Tissue was homogenized with $1 \mathrm{~N}$ Nitric acid. After digestion with $1 \mathrm{~N}$ Nitric acid samples were brought to a constant volume. The digested samples of tissue were analysed for $\mathrm{Cd}, \mathrm{Zn}$ against suitable standards in linear range by inductively coupled plasma-optical emission spectrometer (ICP/OES) Optima 2100DV-Perkin Elmer which is a fast multi-element technique with a dynamic linear range and moderate-low detection limits. The absorption wavelength was $228.802 \mathrm{~nm}$ for $\mathrm{Cd}$ and $206.200 \mathrm{~nm}$ for $\mathrm{Zn}$.

\subsection{Statistical analysis}

All the data were expressed as mean \pm standard deviation (Mean $\pm \mathrm{SD}$ ). Statistical significance between more than two groups was tested using one way ANOVA. Values were considered significant at $p<0.05$. 


\section{RESULTS}

\subsection{Effect of Cadmium on antioxidant enzymes}

\subsubsection{Glutathione s-transferases (GSTs)}

The levels of GST measured in the Cadmium treated group in relation to the control group of $13^{\text {th }}$ day old chick embryo were represented in Fig 1; TABLE 1 . The GST activity was significantly $(p<0.05)$ increased in treated liver in a dose dependent manner. The maximum percentage of induction was observed in $0.06 \mathrm{mg}$ $\mathrm{CdCl}_{2}$ treatment compared to controls. In $0.04 \mathrm{mg} \mathrm{CdCl}$ treated embryos 1.30, 1.32 and 1.33 fold increase in the induction of GST activity in 24, 48 and 72 hrs treatment, was observed respectively. In $0.05 \mathrm{mg} \mathrm{CdCl}$ treated embryos 1.33, 1.33 and 1.34 fold increase in the induction of GST activity in 24, 48 and 72 hrs treatment, was observed. In $0.06 \mathrm{mg} \mathrm{CdCl} 2$ treated embryos 1.34, 1.34 and 1.37 fold increase in the induction of GST activity in 24, 48 and $72 \mathrm{hrs}$ treatment, was observed compared to controls.

\subsubsection{Superoxide dismutase (SOD)}

The levels of SOD measured in the Cadmium treated group in relation to the control group of $13^{\text {th }}$ day old chick embryo were represented in Fig 2 ; TABLE 2 . The SOD activity was significantly $(\mathrm{p}<0.05)$ decreased in treated liver in a dose dependent manner. The maximum decreased activity of SOD was observed in $0.06 \mathrm{mg}$ $\mathrm{CdCl}_{2}$ treatment compared to controls. In $0.04 \mathrm{mg} \mathrm{CdCl}$ treated embryos $0.73,0.64$ and 0.45 fold decrease in the SOD activity in 24, 48 and $72 \mathrm{hrs}$ treatment, was observed. In $0.05 \mathrm{mg} \mathrm{CdCl} 2$ treated embryos $0.53,0.19$ and 0.09 fold decrease was observed. In $0.06 \mathrm{mg} \mathrm{CdCl} 2$ treated embryos $0.18,0.09$ and 0.06 fold decrease in the SOD activity in 24, 48 and 72 hrs treatment was observed compared to controls.

\subsubsection{Catalase (CAT)}

The levels of CAT measured in the Cadmium treated group in relation to the control group of $13^{\text {th }}$ day old chick embryo were represented in Fig 3; TABLE 3. The CAT activity was significantly $(\mathrm{p}<0.05)$ decreased in treated liver in a dose dependent manner. The maximum decreased activity of CAT was observed in $0.06 \mathrm{mg}$ $\mathrm{CdCl}_{2}$ treatment compared to controls. In $0.04 \mathrm{mg} \mathrm{CdCl}$ treated embryos $0.62,0.54$ and 0.45 fold decrease in the CAT activity in 24, 48 and $72 \mathrm{hrs}$ treatment, was observed. In $0.05 \mathrm{mg} \mathrm{CdCl} 2$ treated embryos $0.54,0.40$ and 0.28 fold decrease was observed. In $0.06 \mathrm{mg} \mathrm{CdCl} 2$ treated embryos $0.30,0.18$ and 0.10 fold decrease in the CAT activity in 24, 48 and 72 hrs treatment was observed compared to controls.

\subsubsection{Glutathione peroxidase (GPx)}

The levels of GPx measured in the Cadmium treated group in relation to the control group of $13^{\text {th }}$ day old chick embryo were represented in Fig 4; TABLE 4. The GPx activity was significantly $(\mathrm{p}<0.05)$ decreased in treated liver in a dose dependent manner. The maximum decreased activity of GPx was observed in $0.06 \mathrm{mg}$ $\mathrm{CdCl}_{2}$ treatment compared to controls. In $0.04 \mathrm{mg} \mathrm{CdCl}_{2}$ treated embryos $0.69,0.64$ and 0.61 fold decrease in the GPx activity in 24, 48 and $72 \mathrm{hrs}$ treatment was observed. In $0.05 \mathrm{mg} \mathrm{CdCl} \mathrm{Cl}_{2}$ treated embryos $0.61,0.62$ and 0.60 fold decrease was observed. In $0.06 \mathrm{mg} \mathrm{CdCl}_{2}$ treated embryos $0.57,0.38$ and 0.33 fold decrease in the $\mathrm{GPx}$ activity in 24,48 and $72 \mathrm{hrs}$ treatment was observed compared to controls.

\subsubsection{Glutathione reductase (GR)}

The levels of GR measured in the Cadmium treated group in relation to the control group of $13^{\text {th }}$ day old chick embryo were represented in Fig 5; TABLE 5. The GR activity was significantly $(p<0.05)$ decreased in treated liver in a dose dependent manner. The maximum decreased activity of GR was observed in $0.06 \mathrm{mg}$ $\mathrm{CdCl}_{2}$ treatment compared to controls. In $0.04 \mathrm{mg} \mathrm{CdCl}$ treated embryos $0.66,0.57$ and 0.46 fold decrease in the GR activity in 24,48 and $72 \mathrm{hrs}$ treatment was observed. In $0.05 \mathrm{mg} \mathrm{CdCl} \mathrm{Cl}_{2}$ treated embryos $0.55,0.47$ and 0.34 fold decrease was observed. In $0.06 \mathrm{mg} \mathrm{CdCl} 2$ treated embryos $0.37,0.24$ and 0.11 fold decrease in the GR activity in 24,48 and $72 \mathrm{hrs}$ treatment was observed compared to controls.

\subsection{Effect of Cadmium on non-enzymatic antioxidant; Glutathione (GSH)}

The levels of GSH measured in the Cadmium treated group in relation to the control group of $13^{\text {th }}$ day old chick embryo were represented in Fig 6; TABLE 6. The GSH activity was significantly $(p<0.05)$ decreased in treated liver in a dose dependent manner. The maximum decreased activity of GSH was observed in $0.06 \mathrm{mg} \mathrm{CdCl} 2$ treatment compared to controls. In $0.04 \mathrm{mg} \mathrm{CdCl}$ treated embryos $0.67,0.57$ and 0.47 fold decrease in the GSH activity in 24, 48 and $72 \mathrm{hrs}$ treatment was observed. In $0.05 \mathrm{mg} \mathrm{CdCl}$ treated embryos $0.54,0.44$ and 0.34 fold decrease was observed. In $0.06 \mathrm{mg} \mathrm{CdCl} 2$ treated embryos $0.41,0.30$ and 0.20 fold decrease in the GSH activity in 24,48 and $72 \mathrm{hrs}$ treatment was observed compared to controls. 
Table 1: Levels of GST measured in the Cadmium treated group in relation to the control group of $13^{\text {th }}$ day chick embryonic liver.

\begin{tabular}{|l|l|l|l|}
\hline Treatment & $\mathbf{2 4} \mathbf{~ h r s}$ & $\mathbf{4 8} \mathbf{~ h r s}$ & $\mathbf{7 2} \mathbf{~ h r s}$ \\
\hline Control & $47.261 \pm 0.621^{\mathrm{a}}$ & $47.261 \pm 0.621^{\mathrm{a}}$ & $47.261 \pm 0.621^{\mathrm{a}}$ \\
\hline $\mathbf{0 . 0 4 m g ~} \mathbf{C d C l}_{\mathbf{2}}$ & $61.903 \pm 0.457^{\mathrm{a}}$ & $62.851 \pm 0.558^{\mathrm{b}}$ & $63.275 \pm 0.697^{\mathrm{b}}$ \\
\hline $\mathbf{0 . 0 5 m g ~ C d C l}$ & $63.288 \pm 0.843^{\mathrm{a}}$ & $63.721 \pm 0.529^{\mathrm{a}}$ & $63.370 \pm 0.475^{\mathrm{a}}$ \\
\hline $\mathbf{0 . 0 6} \mathbf{m g ~ C d C l}$ & $63.398 \pm 0.39^{\mathrm{a}}$ & $63.721 \pm 0.533^{\mathrm{a}}$ & $64.763 \pm 0.478^{\mathrm{b}}$ \\
\hline
\end{tabular}

Units: $\mu$ moles of CDNB-GSH conjugates formed per minute per mg protein. Each value represents the mean \pm $\mathrm{SD}(\mathrm{n}=6)$. Different letters are significantly different at the level of $\mathrm{p}<0.05$.

Fig.1. Levels of GST measured in the Cadmium treated group in relation to the control group of $13^{\text {th }}$ day chick embryonic liver.

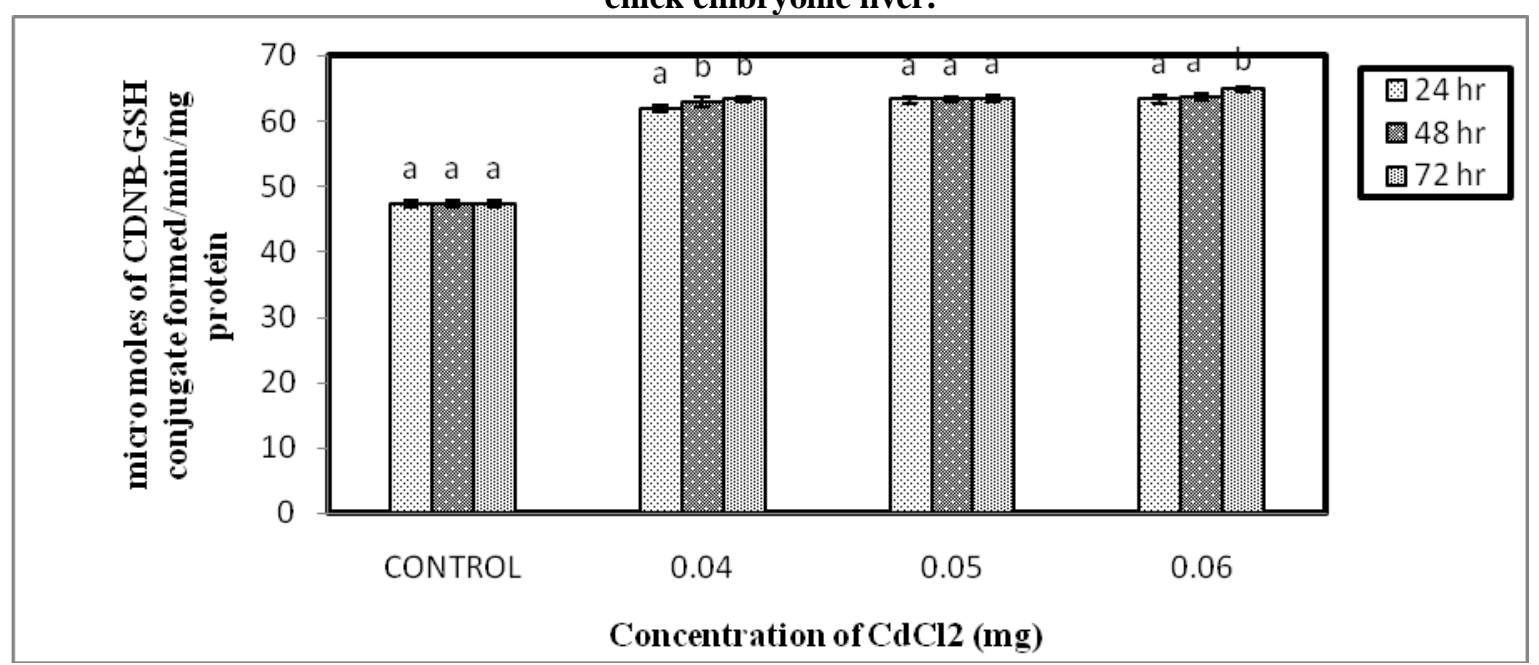

Data expressed as mean $\pm \mathrm{SD}, \mathrm{p}<0.05$.

Table 2: Levels of SOD measured in the Cadmium treated group in relation to the control group of $13^{\text {th }}$ day chick embryonic liver.

\begin{tabular}{|l|l|l|l|}
\hline Treatment & $\mathbf{2 4} \mathbf{~ h r s}$ & $\mathbf{4 8} \mathbf{h r s}$ & $\mathbf{7 2} \mathbf{~ h r s}$ \\
\hline Control & $11.418 \pm 0.532^{\mathbf{a}}$ & $11.418 \pm 0.532^{\mathbf{a}}$ & $11.418 \pm 0.532^{\mathbf{a}}$ \\
\hline $\mathbf{0 . 0 4 m g ~ C d C l}_{\mathbf{2}}$ & $8.41 \pm 0.511^{\mathbf{c}}$ & $7.385 \pm 0.565^{\mathbf{b}}$ & $5.21 \pm 0.532^{\mathbf{a}}$ \\
\hline $\mathbf{0 . 0 5 m g ~ C d C l}$ & $6.108 \pm 0.356^{\mathbf{c}}$ & $2.213 \pm 0.582^{\mathbf{b}}$ & $1.138 \pm 0.657^{\mathbf{a}}$ \\
\hline $\mathbf{0 . 0 6} \mathbf{m g ~ C d C l}_{\mathbf{2}}$ & $2.141 \pm 0.482^{\mathbf{b}}$ & $1.081 \pm 0.455^{\mathbf{a}}$ & $0.745 \pm 0.327^{\mathbf{a}}$ \\
\hline
\end{tabular}

Units: The amount of enzyme required to inhibit 50\% NBT (nitroblue tetrazolium) reduction/mg protein. Data are expressed as mean $\pm \mathrm{SD}$; different letters are significantly different at the level of $\mathrm{p}<0.05$.

Fig.2. Levels of SOD measured in the Cadmium treated group in relation to the control group of $13^{\text {th }}$ day chick embryonic liver. 


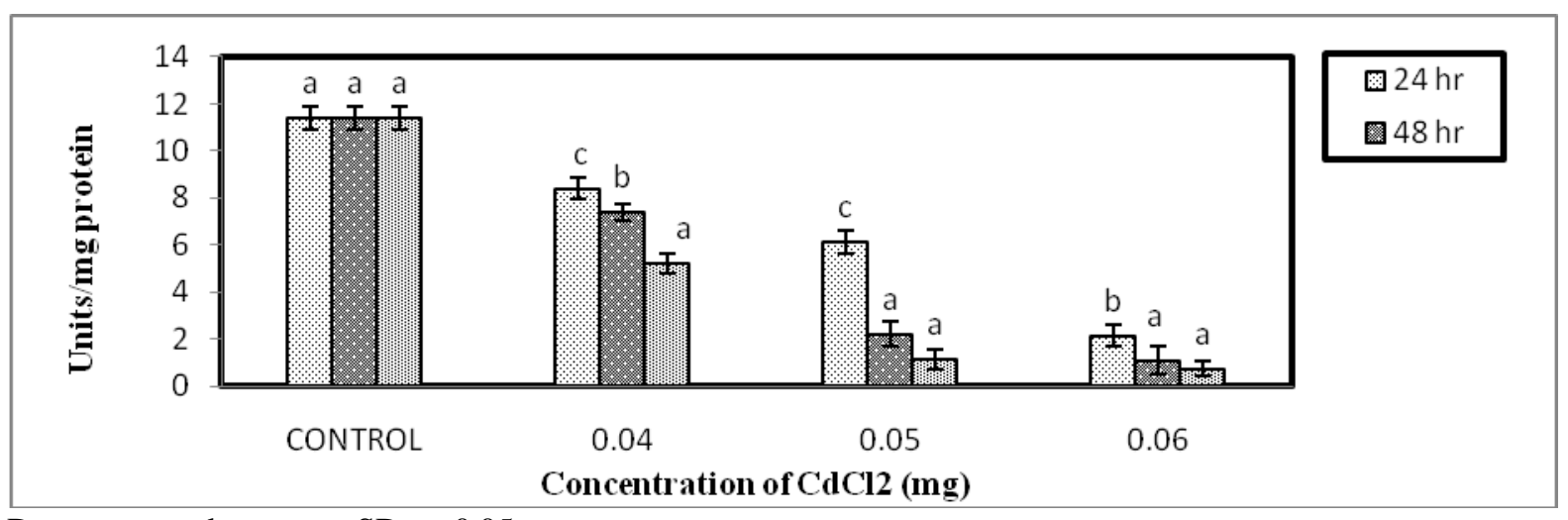

Data expressed as mean $\pm \mathrm{SD}, \mathrm{p}<0.05$.

Table 3: Levels of CAT measured in the Cadmium treated group in relation to the control group of $13^{\text {th }}$ day chick embryonic liver.

\begin{tabular}{|l|l|l|l|}
\hline Treatment & $\mathbf{2 4} \mathbf{~ h r s}$ & $\mathbf{4 8} \mathbf{~ h r s}$ & $\mathbf{7 2} \mathbf{~ h r s}$ \\
\hline Control & $11.353 \pm 0.483^{\mathrm{a}}$ & $11.353 \pm 0.483^{\mathrm{a}}$ & $11.353 \pm 0.483^{\mathrm{a}}$ \\
\hline $\mathbf{0 . 0 4 m g ~ C d C l} \mathbf{2}_{\mathbf{2}}$ & $7.126 \pm 0.300^{\mathrm{c}}$ & $6.243 \pm 0.618^{\mathrm{b}}$ & $5.148 \pm 0.667^{\mathrm{a}}$ \\
\hline $\mathbf{0 . 0 5} \mathbf{m g} \mathbf{C d C l}_{\mathbf{2}}$ & $6.183 \pm 0.762^{\mathrm{a}}$ & $4.58 \pm 0.512^{\mathrm{b}}$ & $3.283 \pm 0.625^{\mathrm{c}}$ \\
\hline $\mathbf{0 . 0 6} \mathbf{m g ~ C d C l} \mathbf{2}$ & $3.445 \pm 0.557^{\mathrm{c}}$ & $2.135 \pm 0.649^{\mathrm{b}}$ & $1.218 \pm 0.742^{\mathrm{a}}$ \\
\hline
\end{tabular}

Units: $\mu$ moles of $\mathrm{H}_{2} \mathrm{O}_{2}$ used per minute per mg protein. Data expressed as mean \pm SD; different letters are significantly different at the level of $\mathrm{p}<0.05$.

Fig.3. Levels of CAT measured in the Cadmium treated group in relation to the control group of $13^{\text {th }}$ day chick embryonic liver.

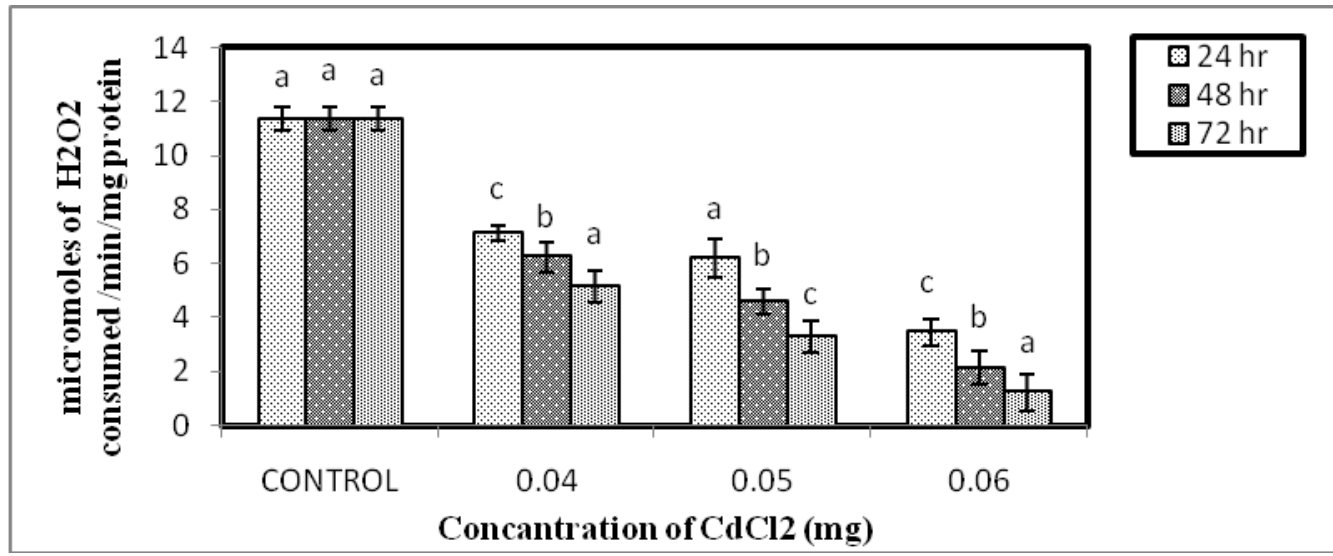

Data expressed as mean $\pm \mathrm{SD}, \mathrm{p}<0.05$.

Table 4: Levels of GPx measured in the Cadmium treated group in relation to the control group of $13^{\text {th }}$ day chick embryonic liver.

\begin{tabular}{|l|l|l|l|}
\hline Treatment & $\mathbf{2 4} \mathbf{~ h r s}$ & $\mathbf{4 8} \mathbf{~ h r s}$ & $\mathbf{7 2} \mathbf{~ h r s}$ \\
\hline Control & $0.168 \pm 0.011^{\mathrm{a}}$ & $0.168 \pm 0.011^{\mathrm{a}}$ & $0.168 \pm 0.011^{\mathrm{a}}$ \\
\hline $\mathbf{0 . 0 4 m g ~ C d C l} \mathbf{C l}_{\mathbf{2}}$ & $0.116 \pm 0.078^{\mathrm{b}}$ & $0.108 \pm 0.0021^{\mathrm{a}}$ & $0.103 \pm 0.0024^{\mathrm{a}}$ \\
\hline $\mathbf{0 . 0 5 m g ~ C d C l}_{\mathbf{2}}$ & $0.104 \pm 0.0033^{\mathrm{c}}$ & $0.100 \pm 0.0025^{\mathrm{b}}$ & $0.096 \pm 0.0023^{\mathrm{a}}$ \\
\hline $\mathbf{0 . 0 6} \mathbf{m g ~ C d C l} \mathbf{C}_{\mathbf{2}}$ & $0.097 \pm 0.0015^{\mathrm{c}}$ & $0.064 \pm 0.0026^{\mathrm{b}}$ & $0.056 \pm 0.0034^{\mathrm{a}}$ \\
\hline
\end{tabular}

Units: $\mu$ moles of glutathione used per minute per g protein. Data expressed as mean \pm SD; different letters are significantly different at the level of $\mathrm{p}<0.05$.

Fig.4. Levels of GPx measured in the Cadmium treated group in relation to the control group of $13^{\text {th }}$ day chick embryonic liver. 


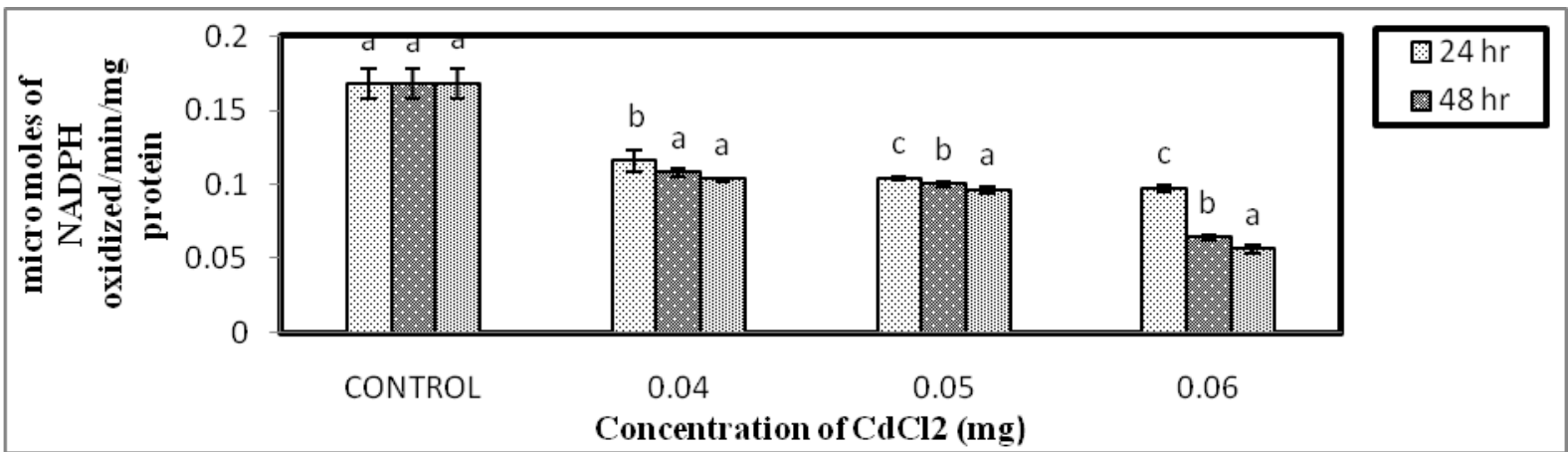

Data expressed as mean $\pm \mathrm{SD}, \mathrm{p}<0.05$.

Table 5: Levels of GR measured in the Cadmium treated group in relation to the control group of $13^{\text {th }}$ day chick embryonic liver.

\begin{tabular}{|c|c|c|c|}
\hline Treatment & 24 hrs & 48 hrs & $72 \mathrm{hrs}$ \\
\hline Control & $9.238 \pm 0.620^{\mathrm{a}}$ & $9.238 \pm 0.620^{\mathrm{a}}$ & $9.238 \pm 0.620^{\mathrm{a}}$ \\
\hline $\mathrm{o.04mg} \mathrm{CdCl}_{2}$ & $6.12 \pm 0.530^{c}$ & $5.306 \pm 0.587^{b}$ & $4.301 \pm 0.610^{\mathrm{a}}$ \\
\hline $0.05 \mathrm{mg} \mathrm{CdCl}{ }_{2}$ & $5.131 \pm 0.599^{c}$ & $4.420 \pm 0.563^{b}$ & $3.215 \pm 0.517^{\mathrm{a}}$ \\
\hline $0.06 \mathrm{mg} \mathrm{CdCl}{ }_{2}$ & $3.420 \pm 0.531^{\mathrm{c}}$ & $2.298 \pm 0.487^{b}$ & $1.108 \pm 0.469^{\mathrm{a}}$ \\
\hline
\end{tabular}

Units: nanomoles NADPH oxidised /minute/ milligram protein. Data expressed as mean \pm SD; different letters are significantly different at the level of $\mathrm{p}<0.05$.

Fig.5. Levels of GR measured in the Cadmium treated group in relation to the control group of $13^{\text {th }}$ day chick embryonic liver.

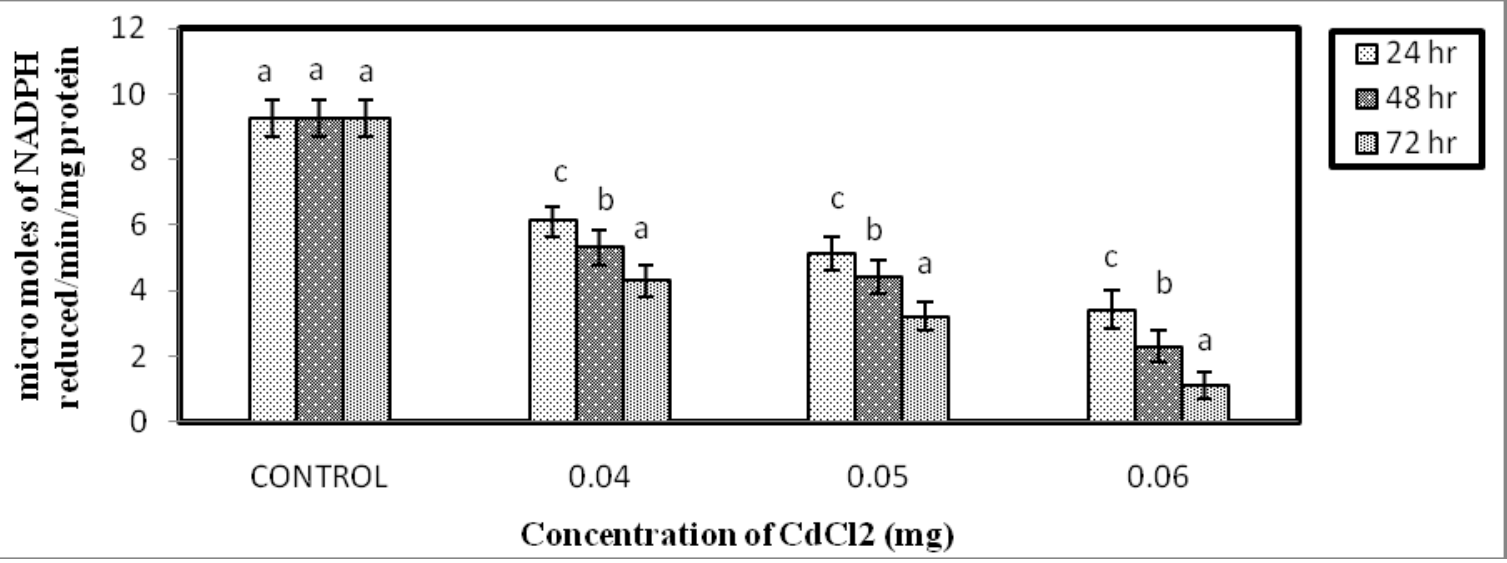

Data expressed as mean \pm SD, $\mathrm{p}<0.05$.

Table 6: Levels of GSH measured in the Cadmium treated group in relation to the control group of $13^{\text {th }}$ day chick embryonic liver.

\begin{tabular}{|c|c|c|c|}
\hline Treatment & 24 hrs & $48 \mathrm{hrs}$ & $72 \mathrm{hrs}$ \\
\hline Control & $29.751 \pm 0.980^{\mathrm{a}}$ & $29.751 \pm 0.980^{\mathrm{a}}$ & $29.751 \pm 0.980^{a}$ \\
\hline $0.04 \mathrm{mg} \mathrm{CdCl}{ }_{2}$ & $20.175 \pm 0.557^{\mathrm{c}}$ & $17.131 \pm 0.567^{\mathrm{b}}$ & $14.223 \pm 0.592^{\mathrm{a}}$ \\
\hline $0.05 \mathrm{mg} \mathrm{CdCl}{ }_{2}$ & $16.121 \pm 0.575^{\mathrm{c}}$ & $13.133 \pm 0.409^{\mathrm{b}}$ & $10.143 \pm 0.505^{\mathrm{a}}$ \\
\hline $0.06 \mathrm{mg} \mathrm{CdCl}{ }_{2}$ & $12.34 \pm 0.553^{\mathrm{c}}$ & $9.141 \pm 0.633^{\mathrm{b}}$ & $5.955 \pm 0.477^{\mathrm{a}}$ \\
\hline
\end{tabular}

Units: $\mathrm{mg} / \mathrm{g}$ tissue. Data are expressed as mean $\pm \mathrm{SD}$; different letters are significantly different at the level of $\mathrm{p}$ $<0.05$.

Fig.6. Levels of GSH measured in the Cadmium treated group in relation to the control group of $13^{\text {th }}$ day chick embryonic liver. 


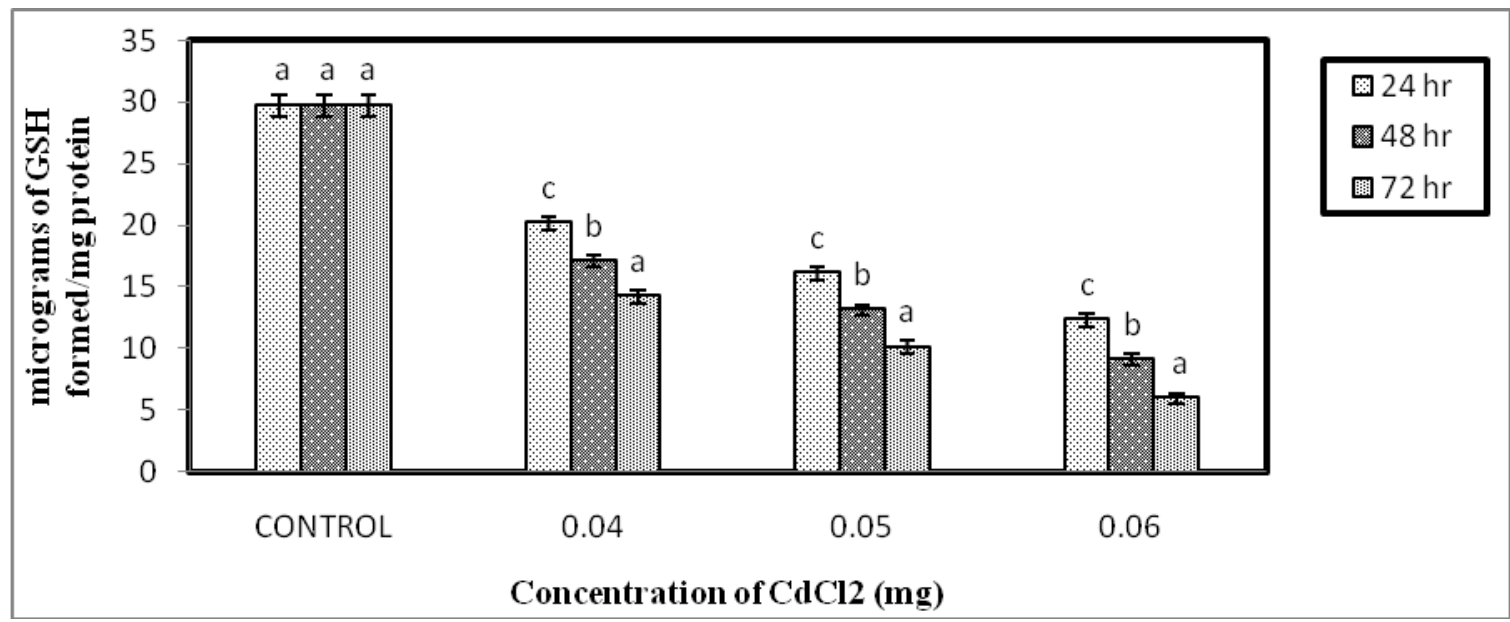

Data expressed as mean $\pm \mathrm{SD}, \mathrm{p}<0.05$.

\subsection{Analysis of Cadmium and Zinc levels in liver tissue}

The ICP OES was used for the determination of Cadmium and Zinc concentration in liver (13 ${ }^{\text {th }}$ day) of control and treated groups. Cadmium and Zinc concentrations in liver tissue of developing chick embryo treated with different concentrations of Cadmium at different time intervals were presented in TABLE 7, 8 \& Fig 7, 8 . In this study Cadmium and Zinc levels in liver were increased with increased concentrations of Cadmium exposure with increased time intervals.

Cadmium levels ranged from $0.107-0.793 \mathrm{ppm} / 500 \mathrm{mg}$ wet tissue. The level of the cadmium in the control group was $0.005 \mathrm{ppm} / 500 \mathrm{mg}$ tissue. In Liver tissue treated with $0.04 \mathrm{mg}$ of $\mathrm{CdCl}_{2}$ the retention of Cadmium concentration at 24, 48 and $72 \mathrm{hr}$ was $0.107 \mathrm{ppm} / 500 \mathrm{mg}$ wet tissue, $0.113 \mathrm{ppm} / 500 \mathrm{mg}$ wet tissue and $0.196 \mathrm{ppm} / 500 \mathrm{mg}$ wet tissue respectively (TABLE 7, Fig 7).

In Liver tissue treated with $0.05 \mathrm{mg}$ of $\mathrm{CdCl}_{2}$ the retention of Cadmium concentration at 24, 48 and 72 hr was $0.306 \mathrm{ppm} / 500 \mathrm{mg}$ wet tissue, $0.393 \mathrm{ppm} / 500 \mathrm{mg}$ wet tissue and $0.412 \mathrm{ppm} / 500 \mathrm{mg}$ wet tissue respectively.

In Liver tissue treated with $0.06 \mathrm{mg}$ of $\mathrm{CdCl}_{2}$ the retention of Cadmium concentration at 24, 48 and 72 hr was $0.715 \mathrm{ppm} / 500 \mathrm{mg}$ wet tissue, $0.764 \mathrm{ppm} / 500 \mathrm{mg}$ wet tissue and $0.793 \mathrm{ppm} / 500 \mathrm{mg}$ wet tissue respectively.

Zinc levels ranged from $0.826-0.973 \mathrm{ppm} / 500 \mathrm{mg}$ wet tissue. The level of the Zinc in the control group was $0.804 \mathrm{ppm} / 500 \mathrm{mg}$ tissue. In Liver tissue treated with $0.04 \mathrm{mg}$ of $\mathrm{CdCl}_{2}$ the Zinc concentration at 24, 48 and $72 \mathrm{hr}$ was $0.826 \mathrm{ppm} / 500 \mathrm{mg}$ wet tissue, $0.831 \mathrm{ppm} / 500 \mathrm{mg}$ wet tissue and $0.854 \mathrm{ppm} / 500 \mathrm{mg}$ wet tissue respectively (TABLE 8, Fig 8).

In Liver tissue treated with $0.05 \mathrm{mg}$ of $\mathrm{CdCl}_{2}$ the Zinc concentration at 24, 48 and $72 \mathrm{hr}$ was 0.871 $\mathrm{ppm} / 500 \mathrm{mg}$ wet tissue, $0.905 \mathrm{ppm} / 500 \mathrm{mg}$ wet tissue and $0.915 \mathrm{ppm} / 500 \mathrm{mg}$ wet tissue respectively.

In Liver tissue treated with $0.06 \mathrm{mg}$ of $\mathrm{CdCl}_{2}$ the Zinc concentration at 24, 48 and $72 \mathrm{hr}$ was 0.926 $\mathrm{ppm} / 500 \mathrm{mg}$ wet tissue, $0.954 \mathrm{ppm} / 500 \mathrm{mg}$ wet tissue and $0.973 \mathrm{ppm} / 500 \mathrm{mg}$ wet tissue respectively.

Table 7: Heavy metal (Cadmium) concentration in tissue (500 mg wet weight) of $13^{\text {th }}$-day old chick embryo liver exposed to different concentrations of Cadmium during embryogenesis at different time intervals (i.e., 24, 48 and $72 \mathrm{hr}$ ).

\begin{tabular}{|l|l|l|l|}
\hline Dose & $\mathbf{2 4} \mathbf{~ h r}$ & $\mathbf{4 8} \mathbf{~ h r}$ & $\mathbf{7 2} \mathbf{~ h r}$ \\
\hline Control & $0.005 \pm 0.000^{\mathrm{a}}$ & $0.005 \pm 0.000^{\mathrm{a}}$ & $0.005 \pm 0.000^{\mathrm{a}}$ \\
\hline $\mathbf{0 . 0 4 m g ~ C d C l}$ & $\mathbf{2}$ & $0.113 \pm 0.001^{\mathrm{b}}$ & $0.196 \pm 0.001^{\mathrm{b}}$ \\
\hline $\mathbf{0 . 0 5 m g ~ C d C l}$ & $0.107 \pm 0.001^{\mathrm{b}}$ & $0.393 \pm 0.001^{\mathrm{c}}$ & $0.412 \pm 0.001^{\mathrm{c}}$ \\
\hline $\mathbf{0 . 0 6} \mathrm{mg} \mathrm{CdCl}$ & $0.306 \pm 0.002^{\mathrm{c}}$ & $0.764 \pm 0.001^{\mathrm{d}}$ & $0.793 \pm 0.001^{\mathrm{d}}$ \\
\hline
\end{tabular}

Units: $\mathrm{ppm} / 500 \mathrm{mg}$ wet tissue weight. Each value represents the mean $\pm \mathrm{SD}(\mathrm{n}=6) . \mathrm{p}<0.05$ compared with control. (ppm - parts per million)

Fig.7. ICP-OES examination of Cadmium metal content in liver tissue of $13^{\text {th }}$-day old chicks exposed to different concentrations of Cadmium during embryogenesis at different time intervals (i.e., 24, 48 and 72 hr). 


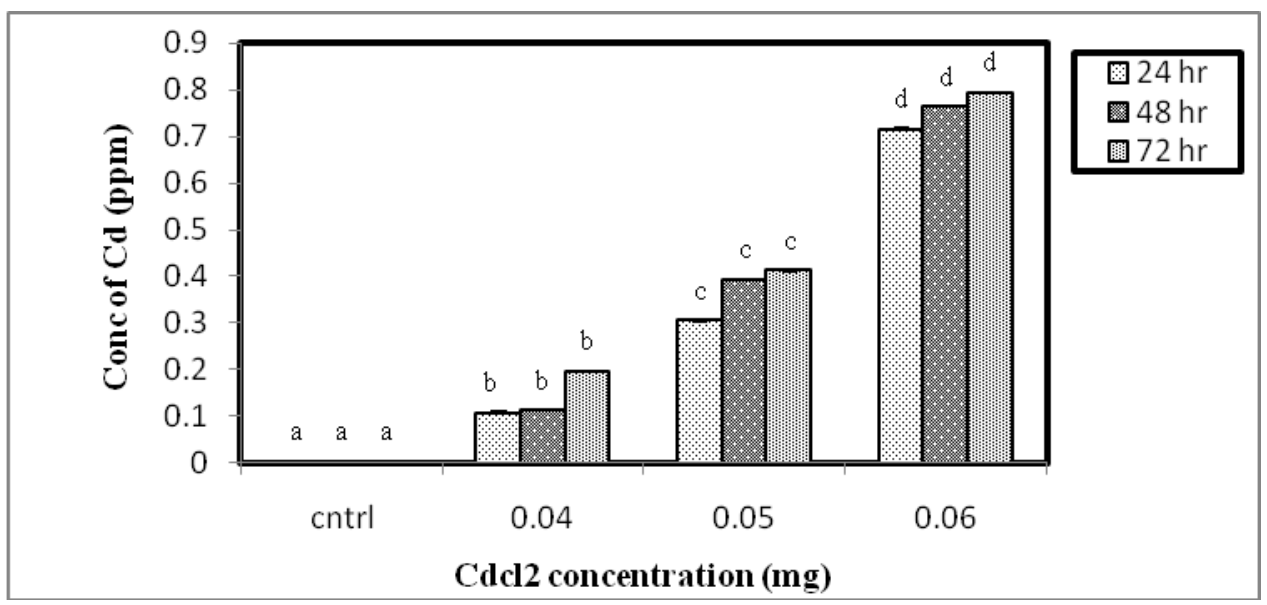

Data expressed as mean $\pm \mathrm{SD}, \mathrm{p}<0.05$.

Table 8: Zinc concentration in tissue $\left(500 \mathrm{mg}\right.$ wet weight) of $13^{\text {th }}$-day old chick embryo liver exposed to different concentrations of Cadmium during embryogenesis at different time intervals (i.e., 24, 48 and $72 \mathrm{hr}$ ).

\begin{tabular}{|c|c|c|c|}
\hline Treatment & $24 \mathrm{hr}$ & $48 \mathrm{hr}$ & $72 \mathrm{hr}$ \\
\hline Control & $0.804 \pm 0.001^{\mathrm{a}}$ & $0.804 \pm 0.001^{\mathrm{a}}$ & $0.804 \pm 0.001^{\mathrm{a}}$ \\
\hline $0.04 \mathrm{mg} \mathrm{CdCl} 2$ & $0.826 \pm 0.001^{\mathrm{b}}$ & $0.831 \pm 0.001^{\mathrm{b}}$ & $0.854 \pm 0.001^{\mathrm{b}}$ \\
\hline $0.05 \mathrm{mg} \mathrm{CdCl} 2$ & $0.871 \pm 0.001^{\mathrm{c}}$ & $0.905 \pm 0.002^{\mathrm{c}}$ & $0.915 \pm 0.002^{\mathrm{c}}$ \\
\hline $0.06 \mathrm{mg} \mathrm{CdCl}{ }_{2}$ & $0.926 \pm 0.001^{\mathrm{d}}$ & $0.954 \pm 0.002^{d}$ & $0.973 \pm 0.002^{\mathrm{d}}$ \\
\hline
\end{tabular}

Units: $\mathrm{ppm} / 500 \mathrm{mg}$ wet tissue weight. Each value represents the mean $\pm \mathrm{SD}(\mathrm{n}=6)$. Different letters were significantly different at the level of $\mathrm{p}<0.05$. (ppm - parts per million)

Fig.8. ICP-OES examination of Zinc metal content in liver tissue of $13^{\text {th }}$-day old chicks exposed to different concentrations of Cadmium during embryogenesis at different time intervals (i.e., 24, 48 and $72 \mathrm{hr})$.

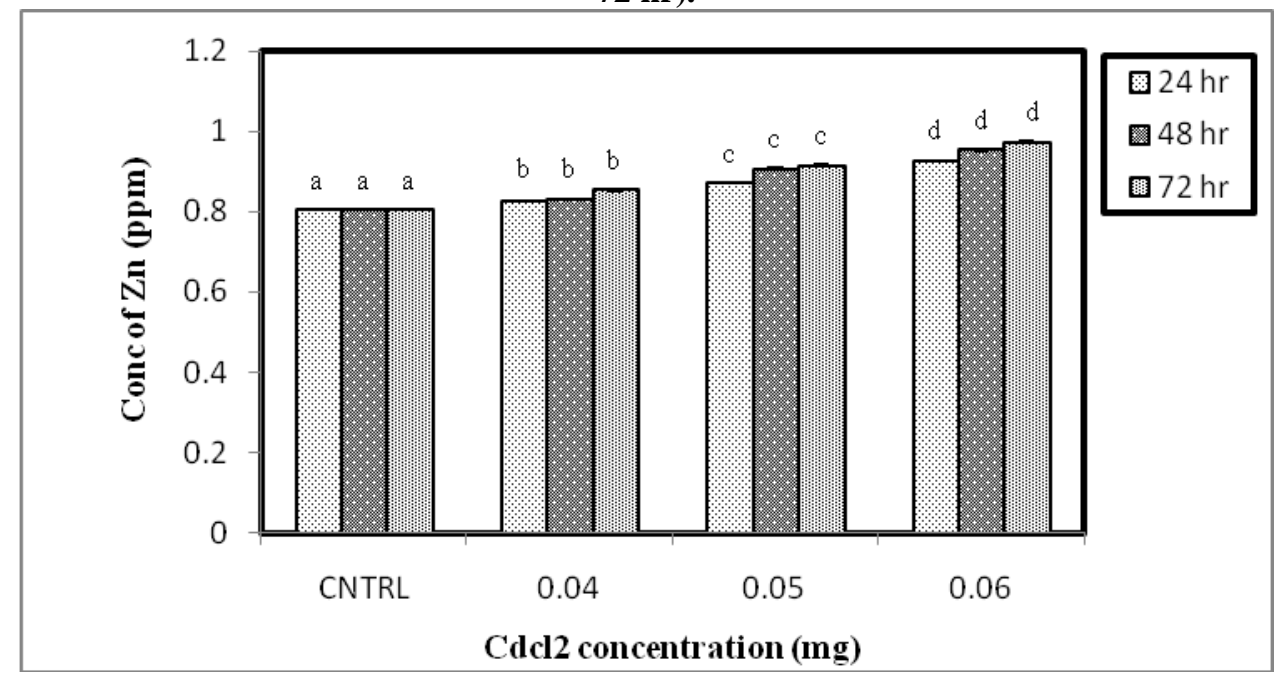

Data expressed as mean $\pm \mathrm{SD}, \mathrm{p}<0.05$.

\section{DISCUSSION}

The results of the present investigation revealed that $\mathrm{Cd}$ induces significant alterations in the levels of certain enzymatic antioxidant enzymes status in liver of $13^{\text {th }}$ day old chick embryo at all specific time intervals. A number of reports concerning the chemical toxicology of metals which are released in the environment by natural as well as anthropogenic sources have been increasing constantly. $\mathrm{Cd}$ has been recognized as one of the most toxic environmental and industrial pollutants. It is an ubiquitous toxic metal that may induce oxidative damage by disturbing the prooxidant antioxidant balance in the tissues. Liver, kidney, lung, testes, and heart are the target organs following $\mathrm{Cd}$ exposure, with the severity of their intoxication dependent on the route, dose, and duration of the exposure to the metal $[35,36]$. Cadmium found a variety of uses in industry, craft and agriculture 
owing to their physical and chemical properties. The environmental burden of Cadmium has been rising substantially by smelter emission in air and waste sewage in water. Such environmental contamination of air, water, soil and food is a serious threat to all living kinds.

The damaging action of $\mathrm{Cd}$ on the antioxidant defense system in liver tissue during $\mathrm{Cd}$ exposure has been extensively studied. It has been reported that the sulfhydryl group of cysteine moiety of glutathione has a high affinity for metals such as $\mathrm{Cd}$, forming thermo-dynamically stable mercaptide complexes which are inert and excreted via the bile $[37,38]$. Exposure to $\mathrm{Cd}$, originating from different sources-air, water, food-may produce effects in organs such as kidneys, liver, lungs, cardiovascular, immune and reproductive systems [39]. Moreover, $\mathrm{Cd}$ is identified as a human carcinogen. Due to complex interactions between $\mathrm{Cd}$ ions and metabolism, a diverse range of cellular responses is found in different organs after Cd-exposure.

The above discussion provides an insight into the role of reactive species in metal induced toxicity. The direct damage may involve conformational changes of bio-molecules or alter specific binding sites. On the other hand, indirect damage is a consequence of metal driven formation of reactive oxygen/nitrogen species involving superoxide, hydroxyl radicals or nitric oxide, hydrogen peroxide and/or endogenous oxidants.

Due to the ease of absorption, accumulation in tissues, and extremely long biological half-life in the body, cadmium is considered one of the most hazardous heavy metals. Due to the exceptionally long biological halflife (10-30 years) in the body, the toxicity of cadmium ions increases with advancing age and may persist after the end of exposure [40]. In animals exposed to cadmium compounds, the ions of this metal are particularly abundant in kidneys, heart and liver, and, to a lesser degree, in pancreas and brain [41]. This can induce irreversible damage to these organs in addition to anemia, osteoporosis and carcinogenic (for kidney, lung, prostate, testis and breast) and teratogenic lesions [42]. The effects at the cellular level are increased oxidative stress, damage to mitochondria, disturbances in trace element (e.g. calcium and zinc) and vitamin metabolism, and disruption of cell signaling pathways [43]. It is nutritionally nonessential and toxic, and it interacts with the metabolism of three essential metals: calcium, zinc, and iron.

In the present study ICP OES analysis was performed to test out the level of accumulated Cadmium and its effect on Zinc levels in the liver of treated as well as control groups. The result showed that maximum levels of Cadmium and Zinc accumulated in liver treated with $0.06 \mathrm{mg} \mathrm{CdCl} 2$ at $72 \mathrm{hr}$. This result is also in accord with previous result, suggesting that liver is the main organ for the accumulation of heavy metals. We observed that the cadmium accumulation was continually increased in liver at a dose dependent manner and inturn caused the induction of Zinc levels in liver tissues. It can be inferred from above studies that Cd affects the homeostasis of essential metal like Zinc since it is an integral component of about 200 metalloenzymes including $\mathrm{Cu} / \mathrm{Zn}$ Superoxide Dismutase which plays an important role in protection against oxidative damage. This in turn reflects its effect on antioxidant defense system. Cd also alters $\mathrm{Zn}$ distribution in body. Since the levels of Zinc increased under Cadmium exposure, excess accumulation of Zinc within cells may disrupt functions of biological molecules like Protein, enzymes and DNA, thus leading to toxic consequences. Thus the Cd and Zinc concentration in the liver increased with dose level of $\mathrm{Cd}$.

\section{CONCLUSION}

From the present study it can be concluded that $\mathrm{Cd}$ accumulation in liver of $13^{\text {th }}$ day old chick embryo is associated with marked alterations in non enzymatic and enzymatic (SOD, CAT, GSH, GR, GPx and GST) components of AOS and in Zinc levels.

\section{ACKNOWLEDGMENTS}

We thank University Grants Commission and DRDO New Delhi, for providing financial support to carry out our research work. Department of Biochemistry of Sri Venkateswara University is financially supported by DST-FIST and UGC BSR, New Delhi.

\section{REFERENCES}

[1] AL Page, MM. El-Amamy, AC. Chang, Cadmium in the environment and its entry into terrestial food chain crops. In: Cadmium. EC Foulkes (eds), Springer-Verlag, New York, 1986, 33-74.

[2] M. Iscan, T. Coban, BC. Eke, Differential combined effect of cadmium and nickel on hepatic and renal glutathione S-transferase of the guinea pig, Environ Health Perspect, 102, 1994, 69-72.

[3] JM. Peters, JR. Duncan, LM. Wiley, CL. Keen, Influence of antioxidants on cadmium toxicity of mouse preimplantation embryos in vitro, Toxicology 99, 1995, 11-18.

[4] R. Zikic, A. Stajn, Z. Saicic, M. Spasic, K. Ziemnicki, V. Petrovic, The activities of superoxide dismutase, catalase and ascorbic acid content in the liver of goldfish (Carassius auratus gibelio Bloch.) exposed to cadmium, Physiol Res 45, $1996,479-481$.

[5] L. Jamba, B. Nehru, MP. Bansal, Redox modulation of selenium binding proteins by cadmium exposures in mice, Mol Cell Biochem, 177, 1997, 169-175.

[6] M. Waisberg, P. Joseph, B. Hale, D. Beyermann, Molecular and cellular mechanisms of cadmium carcinogenesis, a review, Toxicology 192, , 2003, 95-117.

[7] LE. Rikans, T. Yamano, Mechanisms of cadmium-mediated acute hepatotoxicity, J Biochem Mol Toxicol, $14,2000,110-117$. 
[8] E. Lopez, C. Arce, MJ. Oset-Gasque, Cadmium induces reactive oxygen species generation and lipid peroxidation in cortical neurons in culture, Free Radic Biol Med, 40, 2006, 940-951

[9] PG. Wells, GP. McCallum, CS. Chen, JT. Henderson, CJJ. Lee, J. Perstin, TJ. Preston, MJ. Wiley, AW. Wong, Oxidative stress in developmental origins of disease, teratogenesis, neurodevelopmental deficits, and cancer, Toxicol Sci 108, 2009, 4-18.

[10] H.J. Badham, L.M. Winn, In utero exposure to benzene disrupts fetal hematopoietic progenitor cell growth via reactive oxygen species, Toxicol. Sci. 113(1), 2010, 207-215.

[11] J.M Davis, R.L. Auten, Maturation of the antioxidant system and the effects on preterm birth. Semin, in Fetal \& Neonatal Medicine 15(4), 2010, 191-195.

[12] C. Garrel, P.A. Fowler, K.H. Al-Gubory, Developmental changes in antioxidant enzymatic defences against oxidative stress in sheep placentomes, J. Endocrinol, 205(1), 2010, 107-116.

[13] I.O. Imosemi, The role of antioxidants in cerebellar development, A review of literature, Int. J. Morphol, 31(1), 2013, 203-210.

[14] B. Halliwell, J. Gutteridge, Free radicals in biology and medicine, third ed., Oxford University Press, Oxford, 1999.

[15] A. Ferrari, C.I. Lascano, O.L. Anguiano, A.M. D'Angelo, A. Venturino, Antioxidant responses to azinphos methyl and carbaryl during the embryonic development of the toad Rhinella (Bufo) arenarum Hensel, Aquatic Toxicol, 93(1), 2009, 37-44.

[16] C. Garrel, P.A. Fowler, K.H. Al-Gubory, Developmental changes in antioxidant enzymatic defences against oxidative stress in sheep placentomes, J. Endocrinol, 205(1), 2010, 107-116.

[17] J.M. Mates, J.A. Segura, , F.J. Alonso, J. Márquez, Roles of dioxins and heavy metals in cancer and neurological diseases using ROS-mediated mechanisms, Free Rad. Biol. Med,49(9), 2010, 1328-1341.

[18] B. Halliwel, Free radicals and antioxidants - quo vadis? Trends Pharmacol Sci, 32, 2011, 125-130.

[19] R.G. Ahmed, Maternal-newborn thyroid dysfunction, In the Developmental Neuroendocrinology, Ed R.G. Ahmed. Germany, Lap Lambert Academic Publishing GmbH \& Co KG, 2012a, 1-369.

[20] I. Rahman, Pharmacological antioxidant strategies as therapeutic interventions for COPD, Biochim. Biophys. Acta, 1822(5), 2012, 714-728.

[21] J. Limon-Pacheco, M.E. Gonsebatt, The role of antioxidants and antioxidant-related enzymes in protective responses to environmentally induced oxidative stress, Mutat. Res. 674, 2009, 137-147.

[22] ASTDR. Toxicological profile for Cadmium. Available at: www.atsdr.cdc.gov/ToxProfiles/tp.asp?id=48\&tid=15, Accessed November 30, 2010.

[23] L. Jarup, L. Hellstrom, T. Alfven, Low level exposure to cadmium and early kidney damage, The OSCAR study, Occup Environ Med, 57, 2000, 668-672.

[24] R. Bauer, I. Demeter, V. Hasemann, JT. Johansen, Structural properties of the zinc site in Cu, Zn-superoxide dismutase; perturbed angular correlation of gamma ray spectroscopy on the $\mathrm{Cu}, 111 \mathrm{Cd}$-superoxide dismutase derivative, Biochem Biophys Res Commun, 94, 1980, 1296-1302.

[25] D. Beyersmann, C. Block, A.N. Malviya, Effects of cadmium on nuclear protein kinase C, Environ. Health Perspect, 102, 1994, 177-180.

[26] A.L. Blankenship, K.N.M. Hilscherova, K.K. Coady, S.A. Villalobos, K. Kannan, D.C. Powell, S.J. Bursian, and J.P. Giesy, Mechanisms of TCDD-induced Abnormalities and Embryo Lethality in White Leghorn Chickens, Comparative Biochemistry and Physiology Part C Toxicology Pharmacology, 136, 2003, 47-62.

[27] O.H. Lowry, N.J. Rosebrough, A.G. Farr, Randall, Protein measurement with Folin phenol reagent, J.Biol.Chem, 193, 1951, 265275 .

[28] C. Warburg, W. Christian, Determination of DNA content, Biochem, 2, 1941, 310-402.

[29] OW.Griffith, Determination of glutathione and glutathione disulfide using glutathione reductase and 2 -vinylpyridine, Analytical Biochemistry, 106, 1980, 207-212.

[30] H.P. Misra, I. Fridovich, The role of superoxide anion in the auto oxidation of epinephrine and a simple assay for superoxide dismutase, J.Biol.Chem, 247, 1972, $3170-3175$.

[31] H. Aebi, Catalase, In: Methods of enzymatic analysis, Vol. II, Bergmayer, H. U. (Ed.), Academic Press, New York, 1974, 673-683.

[32] I. Carlberg, B. Mannervik, Purification and characterization of flavor enzyme glutathione reductase from rat liver, J.Biol.Chem, $250,1985,5475-5480$.

[33] WH. Habig WB. Jakoby, Assays for differentiation of glutathione S-transferases, Methods enzymol, 77, 1981, 398-405

[34] Wendel A. Glutathione peroxidase: In enzymatic basis of detoxification, Jakoby W.W(Ed) Academic press, New York, 1, 1981, 33335 .

[35] E. Casalino, C. Sblanco, C. Landriscina, Enzyme activity alteration by cadmium administration to rats, the possibility of iron involvement, Arch. Biochem. Biophys, 346, 1997, 171- 179.

[36] A. Stanj, RV. Zikic, B. Ognjanovic, ZS. Saicic, SZ. Pavlovic, MM. Kostic, VM. Petrovic, Effect of cadmium and selenium on the antioxidant defense system in rat kidneys, Comp Biochem Physiol, 117C, 1997, 167-172.

[37] W. Wang, N. Ballatori Endogenous glutathione conjugates, Occurrence and biological functions, Pharmacol. Rev, 50, 1998, 335356.

[38] P. Mohanpuria, N.K. Rana, S.K. Yadav, Cadmium induced oxidative stress influence on glutathione metabolic genes of Camellia sinensis (L.) O. Kuntze, Environmental Toxicology, 22, 2007, 368-374.

[39] BA. Fowler, Monitoring human populations for early markers of cadmium toxicity: a review, Toxicol Appl Pharm 238, 2009, 294300 .

[40] GF. Nordberg, Historical perspectives on cadmium toxicology, Toxicol, Appl. Pharmacol, 238, 2009, 192-200.

[41] L. Jarup, A. Akesson, Current status of cadmium as an environmental health problem, Toxicol Appl Pharm, 238(3), 2009, 201-208.

[42] L. Jarup, M. Berglund, CG. Elinder, Health effects of cadmium exposure - a review on the literature and a risk estimate, Scand $J$ Work Environ Health 24(S1), 1998, 1-51.

[43] H. Czeczot, M. Skrzyck, Cadmium - element completely unnecessary for the organism (in Polish), Postepy. Hig. Med, Dosw, 64, $2010,38-49$. 
